Since protein is required for the formation of precollagen the significance of Ravdin's work becomes obvious, yet it is remarkable that even when protein is deficient healing will proceed normally if methionine is present. Research of great interest in this respect has been going on for some time at the Royal College of Surgeons under the direction of Professor Slome, and has shown that the ill effects of $x$ rays upon wound healing can be overcome by giving cystiamine.

I have quoted the biochemical influences at work in wound healing to indicate the complicated nature of such problems, and I would suggest that if research is to be undertaken along these lines in a clinical unit it is no good entrusting it to a clinician who dabbles in biochemistry. It is necessary to have the appropriate scientist attached to the unit. If he is medically qualified so much the better, partly because he will be more likely to be sympathetic to the clinicians and less likely to be diverted into purely scientific problems without direct application to patients, and partly because if he is given university status in the unit he can also be given an honorary contract with the hospital.

\section{Training of the Young Surgeon}

Bearing in mind the impact of science upon surgery, how should the young surgeon be equipped to meet the situation? Let me say straight away that I think it is a mistake to try to make him into a pseudo-scientist. He should be given the opportunity of acquiring a scientific mode of thought, an attitude of mind, so that faced with a problem in clinical practice he should know how to make accurate and "controlled" observations, if necessary designing a method of investigation appropriate to the problem; he should know how to collect his results and arrange them for analysis, recognizing the margins of error - that is, their reliability and value ; he should be able to make logical deductions from these results which may lead to some general conclusion, perhaps with a practical application. In this way he may contribute in some degree to the science of surgery, or at any rate to the therapeutic art.

To enable him to acquire this scientific outlook he needs a certain basic knowledge of the preclinical sciences. He may be supposed to have acquired this as an undergraduate, but we all know how little of this knowledge survives even the first clinical year. So as a postgraduate he must experience the discipline of a laboratory for a period of two years-whether in a department of anatomy, physiology, pathology, biochemistry, or pharmacology doesn't much matteror if he cannot afford the time for this he should have a really thorough revision course of about six months to give him a better appreciation of the subjects, towards which his own clinical experience will have helped him greatly.

The object of the course or of the laboratory experience is not the mere acquisition of knowledge, but rather to learn where and how to obtain what he may need later for working out his own problems. To live for two years in a laboratory gives a man something he can scarcely obtain from a course of study, however well planned it may be, though it need scarcely be added that it must be a course in which the student has a chance of doing things for himself in practical classes and in a dissecting-room, and in which much of the teaching is done by discussion rather than by lectures alone.
Let me repeat that it is a mistake to think that such a course of study is intended to give a man encyclopaedic knowledge. When he finds his clinical problem he will have to delve much more deeply in search of anatomical, biochemical, or pathological details which a course could not possibly be planned to cover. But his contact with scientific method, either in the laboratory or in the postgraduate course, should afford him guidance in clinical research, which may require laboratory methods as adjuvants but not as ends in themselves, thus distinguishing the work of the clinician from that of the pure scientist.

For the objective of the clinician, however scientific his bent, must always be the treatment of a patient ; and it will be only by the results he obtains in the alleviation of suffering and, if possible, in the cure of disease that the success of his labours can be judged.

REFERENCES

Dunphy, J. E., and Udupa, K. N. (1955). New Engl. J. Med., 253, 847.

Hadfield, G. (1951). Ann. Roy. Coll. Surg. Engl., 9, 397.

Sissons H A. and Hadfield, G: J (1951). Brit. J. Surg., 39, 172.

\section{ACQUISITION OF A B-LIKE ANTIGEN BY RED BLOOD CELLS}

BY

C. CAMERon, M.B., Ch.B.

FRANCES GRAHAM, M.B., Ch.B.

East of Scotland Blood Transfusion Service, Dundee

I. DUNSFORD, Ph.D.

National Blood Transfusion Service, Sheffield

GRETCHEN SICKLES, M.D.

Division of Laboratories and Research, New York State Department of Health

C. R. MACPHERSON, M.D.

Clinical Laboratories, Ohio State University Hospital, Columbus, Ohio

A. CAHAN, M.D.

Knickerbocker Foundation, New York

RUTH SANGER, Ph.D.

AND

R. R. RACE, Ph.D., M.R.C.S., F.R.S.

Medical Research Council Blood Group Research Unit, The Lister Institute, London

In the past four years we have tested the blood of seven patients whose red cells undoubtedly possess a $B$ antigen of some kind but whose serum contains an apparently normal $\beta$ (anti-B). We have gradually come to recognize that the $B$-like antigen in these people is an acquired and not a genetic character and that it is probably connected with old age or disease, or both.

There have been several reports of peculiar B reactions which are referred to in the discussion below, but only two of them appear to be of the kind we are describing: both were briefly mentioned by Stratton and Renton (1958). 
TABle I.-Some Details of the Seven Patients

\begin{tabular}{|c|c|c|c|c|c|c|c|}
\hline Patient & Age & $\begin{array}{c}\text { Year } \\
\text { of } \\
\text { Death }\end{array}$ & $\begin{array}{l}\text { ABO } \\
\text { Group }\end{array}$ & $\begin{array}{l}\text { Secretion } \\
\text { and } \\
\text { Lewis }\end{array}$ & Disease & Available Family & $\begin{array}{c}\text { Agglutination Reacions } \\
\text { of Routine \& Serd with } \\
\text { Patien! Cells }\end{array}$ \\
\hline Mr. La. (Dundee) $\quad$. & 85 & 1955 & $\mathbf{A}_{1}(\beta)$ & $\operatorname{Le}(a-)$ & $\begin{array}{l}\text { Legs amputated because } \\
\text { of gangrene }\end{array}$ & & About 1 in 3 positive \\
\hline Mrs. Al. (New York) .. & 87 & 1956 & $\mathbf{A}_{1}(\beta)$ & & Carcinoma ul cervix & $\underset{(\alpha, \beta)}{\operatorname{Cirild}} \mathbf{A}_{1}(\not \beta)$, shild $\mathrm{O}$ & All positive $(10)$ \\
\hline $\begin{array}{l}\mathbf{M}_{\mathrm{r}} \text {. Hol. (Sheffield I . } \\
\mathrm{M}_{\mathrm{r}} \text { Ha. (Dundee) }\end{array}$ & $\begin{array}{l}86 \\
77\end{array}$ & $\begin{array}{l}1950 \\
1958\end{array}$ & $\begin{array}{l}\left.\mathbf{A}_{1}\right)(\beta \\
\left.\mathbf{A}_{1}\right)(\beta\end{array}$ & $\begin{array}{l}\text { Vuni-sec. (A, } \\
B, \text { and } H) \\
\text { Le(a+b-) }\end{array}$ & $" \quad "$ " colon & $\begin{array}{l}2 \text { sons and } 2 \text { daughters, } \\
\text { all } A_{1}(\beta)\end{array}$ & $\begin{array}{l}\text { About } 1 \text { in } 3 \text { pos } 1 . \\
(12 \text { out of } 31)\end{array}$ \\
\hline Mrs. Tu. (Grunsby, . . & 42 & Alive & $A_{1}(\beta$ & $\begin{array}{l}\text { sec. }(A \text { and } \\
\text { If, not B) } \\
\text { Le(a-b+? }\end{array}$ & $\begin{array}{l}48 \text { abscess of appendix } \\
\text { adhesions, obstruction } \\
\text { etc. } 1957 \text { cholecyste }\end{array}$ & $\begin{array}{l}\text { Sistel and brothes } \mathbf{A}_{\mathbf{1}} \\
(\beta) \text { child } \mathbf{A}_{1} \quad(\beta), \\
\text { stillbirth A }\end{array}$ & All positive (19; \\
\hline Mr. Ca. (Dundee: $\quad$.. & 61 & .. & $\mathbf{A}_{1}(\beta)$ & $\begin{array}{l}\text { Sec. (A and } \\
\begin{array}{c}\text { H, not } B) \\
\text { Le }(\mathrm{a}-)\end{array}\end{array}$ & Carcinoma of rectum & $\begin{array}{l}\text { Sister and } 2 \text { brothers } \\
\mathbf{A}_{1}(\beta) \text {, brother } 0 \\
(\alpha, \beta) \text {, son } \mathrm{O}(\alpha \beta)\end{array}$ & $\begin{array}{l}\text { Few positive (9 oul of } \\
56 \text { ) }\end{array}$ \\
\hline Mrs. Fr. (Columbus) .. & 68 & 1958 & $\mathbf{A}_{1}(\beta)$ & Le $(a-)$ & ., colon & $\begin{array}{l}\text { Brother } \mathbf{A}_{1}(B) \\
\quad \text { dauginters } \\
\left.\text { son } O(\alpha)^{2}\right)\end{array}$ & $\begin{array}{l}\text { Nearly all positive } 13 \\
\text { out of } 1+4\end{array}$ \\
\hline
\end{tabular}

The peculiarity in each of the seven cases was recognized during grouping before possible transfusion At an early stage in the investigation of several of the samples the possibility of chimerism was considered because in the positive tests with $\beta$ many cells were left unagglutinated and this gave the appearance of a mixture of blood. However, the presence of $\beta$ in the serum, the absence of signs $(\hat{i}$ mixtures in other systems, and the fact that none of the patients is known to have had a twin ruled out the possibility of chimerism. Some details of the patients are given in Table I.

\section{Serological Details Red Cells}

A striking fact is that all the patients are group $A_{1}$ however, the main peculiarity is that the red cells were agglutinated by some $\beta$ sera. As can be seen from Table I, individual samples varied in the proportion of $\beta$ sera with which they reacted. In order to make some comparison possible the $\beta$ sera mentioned in the last column of the Table are confined to those kindly provided by the Blood Group Reference Laboratory; each serum is a pool from six donors who had not been artificially immunized.

The patients' cells never reacted as strongly with any $\beta$ as did normal $\mathrm{B}$ cells. Table. II shows that the strength of reaction of the patients' cells is not entirely dependent

TABle II.--Reactions of Cells of Four Patients with Five $B$ Sera

\begin{tabular}{|c|c|c|c|c|c|c|}
\hline & & \multirow{3}{*}{$\begin{array}{c}\text { Titre } \\
\text { for } \\
\text { Normal } \\
B \\
\text { Cells }\end{array}$} & \multicolumn{4}{|c|}{ Reacitons with Undiluted $\beta$} \\
\hline & & & \multicolumn{4}{|c|}{ Cells } \\
\hline & & & $\mathrm{Mr} . \mathrm{Ha}$. & Mrs. Tu. & Mr. Ca. & Mrs. Fr. \\
\hline $\begin{array}{ll}1 & 222 \\
3 & 227 \\
13 & 241 \\
\beta & 243 \\
\beta & 252\end{array}$ & $\begin{array}{l}\ldots \\
\because . \\
\ldots\end{array}$ & $\begin{array}{l}256 \\
256 \\
128 \\
256 \\
256\end{array}$ & $\begin{array}{l}\bar{t} \\
\bar{t}\end{array}$ & $\begin{array}{c}++ \\
++ \\
++ \\
(+) \\
+++\end{array}$ & $\overline{\bar{z}}$ & $\begin{array}{c}++ \\
(+) \\
+++ \\
+\overline{+}+\end{array}$ \\
\hline
\end{tabular}

on the strength of the $\beta$ in these pooled sera. But, in general, the stronger the $\beta$ the more likely it is to react with such cells; for example, the cells of Mrs. $A_{1}$. were agglutinated by all of 10 Reference Laboratory $\beta$ but by only 27 out of the 45 unselected $\beta$ from blood donors; again, the cells of $\mathrm{Mr}$. Ca. were agglutinated by 9 out of 56 Reference Laboratory $\beta$, but by only 2 out of 360 unselected $\beta$ sera.
The B-like antigen seems to have the same specificity in the different samples of cells, though it varies in quantity: $\mathrm{Mr}$. $\mathrm{Ca}$. was the weakest reactor of the seven patients, and the relatively few $\beta$ sera that agglutinated his cells invariably agglutinated those of $\mathrm{Mr}$. Ha., who was a little higher in the series; these same $\beta$ sera were those which agglutinated most powerfully the cells of Mrs. Fr. and Frs. Tu., who were strong reactors.

It has been mentioned that a large number of unagglutinated cells was a striking characteristic of the positive reactions with $\beta$ sera ; however, very few of the cells of Mrs. Tu., the strongest reactor, were left unagglutinated by $\beta 252$ (Table II) when the tests were done at $6^{\circ} \mathrm{C}$. (Most of the tests were done at about $20^{\circ}$. C., for in general the reactions were only slightly better at $6^{\circ} \mathrm{C}$.) The fact that only a negligible number

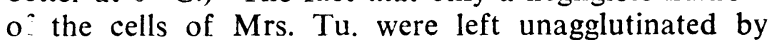
extracts of Dolichos biNorus $\left(\alpha_{1}\right)$ and Ule $\mathrm{R}$ europaeus (anti-H) showed that, in this case at least, the same cells must be carrying $\mathrm{A}_{1}$ and $\mathrm{H}$ as well as the B-like antigen.

Only the cells of Mrs. $A_{1}$ were tested with an antiserum made by a rabbit against human $B$ cells: the result was the same as with human $\beta$-large agglutinates and many unagglutinated cells.

Inhibition tests in all but the first case $(\mathrm{Mr}$. La. not tested) confirmed the specificity of the reaction with $\beta$ sera: the reaction was strongly inhibited by saliva from $\mathrm{B}$ and $\mathrm{AB}$ secretors, but not at all by saliva from $O$ and $A$ secretors or non-secretors; the reaction was very weakly inhibited by saliva from $B$ and $A B$ nonsecretors, and this was to be expected of a weak $\beta-B$ reaction.

Elution tests, by the heating method, further confirmed the specificity of the reaction with $\beta$ sera; these tests were done on five of the cases.

The cells of Mrs. Al. gave up $\beta$ after exposure to a $\beta$ serum capable of agglutinating them. The cells of Mr. Ha. gave up $\beta$ after exposure to two $\beta$ sera capable of agglutinating them; no $\beta$ was given up after exposure to two $\beta$ sera that did not agglutinate his cells. The cells of Mrs. Tu. gave up $\beta$ after exposure to $\beta 222$ (Table II). The cells of $\mathrm{Mr}$. Ca. gave up $\beta$ after exposiure to $\beta 252$ (Table I) but not after exposure to three $\beta$ sera which did not agglutinate them. The cells of Mrs. Fr. gave up $\beta$ after exposure to two $\beta$ which had agglutinated them and to one that had not ( $\beta$ 243, Table II). Each elution test was controlled by normal $A_{1}$ cells and, as expected, no $\beta$ was given up (in the tests on Mrs. Al. the control cells were group O). 
On no occasion was enough $\beta$ removed from the sensitizing serum for an appreciable fall in $\beta$ content to be demonstrated.

The B-like antigen can fluctuate in strength : further samples from three of the patients taken after an interval of time showed the antigen to be weaker in two and stronger in one.

A third sample from Mr. Ha., taken a few days before he, died, gave weaker reactions with $\beta 241$ and $\beta 252$ than did two earlier samples taken six and five weeks before. (The reactions shown in Table II are those of the second sample.) A second sample from Mr. Ca., taken three months after the first and two months after the local resection of his growth, failed to react with three $\beta$ sera that had agglutinated his first sample. A second sample from Mrs. Tu., taken seven months after the first (recorded in Table II), reacted more strongly than before when tested with $\beta 252$ and $\beta 243$.

Attempts to wash the B-like antigen from red cells failed : after 12 washings the cells of Mrs. Tu. reacted as well as ever with $\beta$. Treatment of the cells with ficin increased the strength of their reaction with $\alpha$ and with $\beta$.

The cells of all seven patients were tested against AB sera (two sera with the cells of $\mathrm{Mr}$. Hol., six or more with the cells of other patients): two of the patients showed a slight degree of polyagglutinability. The cells of Mrs. A1. were agglutinated by 5 out of $57 \mathrm{AB}$ sera ; but the B-like antigen was clearly present as well, for the cells were agglutinated by a much higher proportion of unselected $\beta$ sera ( 27 out of 45 ). The cells of the second sample of Mrs. Tu. showed some polyagglutinability that had not been present in the earlier sample: they were weakly agglutinated by 12 out of $36 \mathrm{AB}$ sera. The polyagglutination was not inhibited by $B$ secretor saliva, as judged by tests with the most strongly reacting of these $A B$ sera.

There was nothing unusual about the MNSs, $\mathbf{P}, \mathbf{R h}$, Lutheran, Kell, Lewis, or Duffy groups of the patients.

The ABO groups of available relatives of the patients are given in Table $\mathbf{I}$. Their significance is discussed below.

\section{Serum}

The $\beta$ in the serum of the seven patients appeared normal. It could be strongly inhibited by $B$ and $A B$ secretor saliva but not by other salivas. Each serum was tested against six or more samples of $B$ cells and six or more samples of $A$ and $O$ cells. One serum, that of $\mathrm{Mr}$. Ha., has been tested against 70 samples of B cells and agglutinated them all.

Sera from the last four patients in Table I have been tested against each other's cells. Only one of the 16 tests was positive: the $\beta$ of $\mathrm{Mr}$. Ha. agglutinated the cells of Mrs. Tu. The negative reaction of the cells of Mrs. Fr. with her own and the other three sera was confirmed by elution tests.

At $24^{\circ} \mathrm{C}$. the titre of the $\beta$ in the serum of these lour patients was: Mr. Ha. 32, Mrs. Tu. 8, Mr. Ca. 4, and Mrs. Fr. 2. Only the serum of Mrs. Fr. failed to react with B cells at $37^{\circ} \mathrm{C}$. All four sera contained anti-T.

B substance was looked for in the serum of one of the patients, but none could be demonstrated : the serum of Mrs. Tu., after removal of the $\beta$, failed to inhibit a normal $\beta-B$ reaction. Normal $A_{1}$ cells were unchanged after incubation for 16 hours at $37^{\circ} \mathrm{C}$. in the serum of Mrs. Tu.

\section{Saliva} British
Medical Journal

Saliva was collected from three of the patients. $\mathrm{Mr}$. Ha. was a non-secretor (of A, B, andH) ; Mrs. Tu. and Mr. Ca. are both secretors of $A$ and $H$ but not of $B$. All three salivas contained Le ${ }^{a}$ substance. None of the samples inhibited the positive reaction of $\beta$ sera with cells of Mr. Ha. or Mrs. Tu.

\section{Discussion}

The presence of a B-like antigen in the red cells of the seven patients is proved by the reactions with $\beta$ sera and by the specific inhibition of these reactions by saliva from secretors of $B$.

The serological behaviour of the seven patients is so alike and so characteristic that we are assuming that they all represent the same phenomenon.

The B-like antigen is an acquired character. This conclusion terms inescapable from the convergence of several lines of argument, none of which on its own is absolutely decisive.

1. Mrs. Al., Mr. Ca., and Mrs. Fr. all have O children, and their genotypes are therefore $\mathrm{A}_{1} \mathrm{O}$. This is the best evidence that they have no kind of $B$ gene. Furthermore, no other example of the B-like antigen has been found in 19 available sibs or children of the patients (see Table I).

2. Against No. 1 it could be argued that the patients have some kind of $B$ gene which is capable of expressing itself only in the presence of $A$ :but if this were so several of the 15 group A sibs or children of the patients should have had the B-like antigen-but none of them did.

3. Mrs. Ttu. and Mr. Ca. are secretors, and their saliva contains $\mathrm{A}$ and $\mathrm{H}$ but not $\mathrm{B}$. Certain weak red-cell antigens corresponding to rare alleles of $A$ and $B$ are not detectable in the saliva of secretors; but an antigen of the strength of that of Mrs. Tu. would certainly be expected in the saliva were it inherited.

4. Experience with further samples of the cells of $\mathrm{Mr}$. Ha., Mrs. Tu., and Mr. Ca. shows that the B-like antigen may be a transient character.

5. As is discussed below, the B-like antigen appears to be associated with age or disease or both.

The absence of blood group $O$ from the list of patients is highly significant: excluding $\mathrm{B}$ and $\mathrm{AB}$ people, in whom the change we are describing could not be detected even if it could occur, the probability that seven consecutive people (each of whom happens to have an English or Scottish name) should all have the antigen $A$ cannot be greater than 1 in 200 . It remains to be seen whether the change can happen to $A_{2}$ as well as to $A_{1}$ If further cases continue to be $A_{1}$ a total of 23 will have to be reached before the lack of $A_{2}$ becomes really significant. The change is probably independent of secretion, for one of the three patients from whom saliva was available was a non-secretor, whilte the other two were secretors.

We have not found any evidence that the $\beta$ in the sera of the seven patients is abnormal. There is therefore no hint that certain people are predisposed to the antigen change by the absence of some component of the $\beta$ complex.

Of peculiar B samples described in the literature all three can be distinguished from the kind we are now reporting by the absence of $\beta$ from the serum or by the presence of $B$ in the saliva; most differ in both respects (Mäkelä and Mäkelä, 1955; Moullec, Sutton, and Burgada, 1955 ; Yokoyama, Stacey, and Dunsford, 
1957; Armstrong; Gray, Race; and Thompson, 1959; Levine Celano, and Griset. 1958; Boorman and Zéthrn, 1958). In fout of the six cases the antigen was proved to be intherited. Formaggio (1953) mentions, in passing: an $\mathbf{A B} \mathbf{B}^{\prime}$ with $\beta$ 'in the serum. but no detaits are given? The two remaining cases look very: like our sewen. The following is taken if rom Stratton land Rentor (1958)

"Case 28. Mrs. B. L appeared to ber AABO. Her: A antigen was normal and her serum cotnamed 'an apparentty normal anti-B but no anti $A^{\star}$ Her cells were: agghatinated at $16^{\circ} \mathrm{C}$. by 13 out of 52 group $A$ sera, and this aggitutination was inhibited by the salive of group $B$ individuals only. Her cells were not agghutinated by: 36 group $A B$ sera.

"Case 29. Mr H R atso appeared to be $A_{1} B$ ? with a armal $A$ antigen and apparently normal antg $B$ in the serum His cells were agglutinated hy 34 - wat of 36 group A sera at $16^{\circ} \mathrm{C}$. The reactions varied from + to +++ in strength and were inhibited by gronpl Brativa onty His cells were not agglutinated by 25 group Aptsera. The reactions in this case were stronger than in the :preceding one:"

Dr. Stratton and Dr. Renton $r$ ve kundly allowed us to quote further detaits about their patients Mrs. B. L., xge 76 (1n 1956), wus suffering from a strangulated femoral hernia, one son was $A_{f}$, the other: appeared to be $O$. but his sample was infected and the results were not considered finatty conclusive. Mr. H. R. died in 1956, aged 59; in 1946 he had caxcinoma of the colon and in 1956 a leg: was amputated for gangrene; two brothers andhasister wece group $\mathrm{O}$ and his wife and child were: group $B$,

The A antigen is: known: to be atteeted by blood disease? this was adtambrated by vaw Loghenay Dorfmeier, and? vaw der: Hast (1957) ! and? ppoved I by Stration Renton, and Hancock (1958)! The two patients so fas r reported were gromp A bav thieir red cells lost the farculty of being a geturinated by $\alpha$. Sucb danagee to a misting a ntigen seems easiec to understandsthan: does the acquisition, which we are deseribings of a new one. It is strikingy that the acquired antigen shoubd mimic that prodaced by the allete B; thoughnhad it not done serit would probab have escaped notice.

The acquisition of a $\mathrm{B}$-4ike antigen by peopte of group . A may be associated with age or disease or both? If the change could becbronghtabout by disease alone it should have beenr recogaiaed before in younger patients; the change certaining cannot happen to young or middle. aged, healthy, pooples or it I would, stirety: have : been recognized longzaza in bloadudonors: Five of the seven. patiends had cancer:; this could nean that the acquisitions is associated with the diseasec of some condition secondany, to the disease, steb: as, anaemia or: abnowmalitios: of ther plasma; of it could i simply mean. that cancer is a very common: camse of the blood grouping of old people.

The observations s here repotted rave' an nember of $t$ questions thas ondy more workn may answer! We ongh to known whether' the chinge can happen to healthy old people. In any case, many nwe pasients with the $B$ - 1 ike antigen will surely be foomd; a d brochenmical investigation of the plasma as "wefp 'as ftirther serodiggical 'studiles: may give some clue to the cause of this change:

\section{Summany}

Seven examphes of blood grotmp $A_{i}^{*}(\beta)$ axe detserifed whicht were peeuliä because the redi cells: were agghetina ted by a proportion of $f \beta$ serat. This reaction:

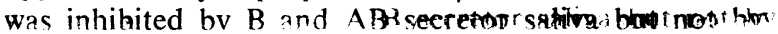

A or $\boldsymbol{O}$ secreton sativa; The $\beta$ in the serum of the served: patients: appeared to be nommal. The sabivat of : threet of the patients was tested: two of them were secretors and their: saliva contained $A$ and $H$ but $n$ not $B$.

The absence of group $\mathbf{O}$ persons amongst the sever. patients is highty significant.

Evidence is produced that the B-like antigen is' not: inherited but is an acquired character. The acquisition may be connected with old age or illness or bothr.

We: are indebted to Dr. S: Varadi, of Sheffeld, and Dr: L. M Gerhis; of Grimsby; who referred the samples from Mr. Hot and Mts. Tu. We alse thank Miss sean: Neades and Parricia Tipperti of the Bood Goup Research Unit, and Miss M B Banber aad Miss Sheida Stacey, of the Regional: Transfusion Centre, Sheffelds who have been. responsible for a geat many of the tests:

\section{REFERENCES}

Atmstrong, C. N., Gray, J. E., Race, R. R., and Thompson, R: B: (1997). Binit med. J., 2, ,605.

Boorman. K. and Zèillin, R. A. (1958) Programme VII Congr. Inr Sóc Btood Transfustion; p..178:

Formaggio, T. G. (1993)., Z: Immun +forsohis 110, 1.

Levine: P. Celano, M and Griset,.. T. (1958) Proc. VI Conge. lht. Soc. Bl'sod Transtasion, p: 132 .

Loghom. J. J. van. Dorfmeier; H. and iHant; M: van der:(1997). Vow Sang (Basel), 2, 16

Mäkelä, O., and Mäkelä, P. (1955). Ann. Mèd. exp. Fenn., 33, 33. Moultec, J., Sttton; E, and Bungada; M. (1995). Rev. Hématis 10,574

Stratton. F., and Renton, P. H. (1958) Practical Blood Grouping, p:' 112.' Błack well!! Oxford!

Y - and Hancock, J.' A. (1958), Nature $\{$ Londw), 181, 62.

Yokoyama," M. Stacey, S. M., and. Dunsford, I. (1957). Vox Sang. 'Btisel',' 2,348 '

\section{A* WeAK B* ANTIGEN; PROBABLY AGQUIRED:}

BY

GAROL YNM. GILES; B.SE

A. E. Mourant; D.M., D.Phif., M.RX.P:

DUROTHY MA.PARHAN.M.RASE, LRXCR.

Médical R'seareh" Councib' Btood G Goup' Réference Labbratoryy Lister I listivudes London.

J. R.HORLEY, M.L, RS.

ANE :

K..J.TAPSON, KLMLLT.

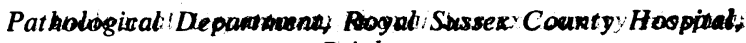
Brighton

Variants of the 'B blood-group antigen are very much rarer than variants of $A^{\prime}$, and there are no chear-cut subgroups of $B^{\prime}$ corresponding to $A_{2}$ and $A_{3}^{*}$. Kace and Sanger (1958) reviewed the few cases mentioned' in the literature, and Cameron et al. (1959) have, since the

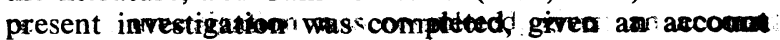
of seweral cases which appeax simitar to the one hera described; we axe indebted to them for allowing us to read thein paper before publication.

Theepatient; a narrieddwormantagedc 57, was admoitted to the Roynl St suffering: from i carcinone of the cotor, with lirer

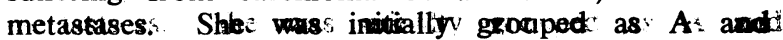
transfused withy groups, $A^{\ddagger}$ bloods without il : eflects: When furtber transfosion was needed a: new test! appoaxedito show thas thet pratient's groupr was AB. It 